\title{
PEDAGOGIA DA CURA: FORMAÇÃO E PRÁTICAS COTIDIANAS DE DONA DIONÉIA
}

\author{
PEDAGOGY OF HEALING: FORMATION AND DAILY PRACTICES OF DONA DIONÉIA \\ PEDAGOGÍA DE LA CURA: FORMACIÓN Y PRÁCTICAS COTIDIANAS DE DOÑA DIONÉIA
}

\author{
SOUSA, Marcio Barradas ${ }^{1}$ \\ BUECKE, Jane Elisa Otomar ${ }^{2}$
}

\section{RESUMO}

Este artigo analisa a formação de Odinéia dos Santos Barbosa como curadora evangélica da Comunidade quilombola de Abacatal - PA. Baseia-se nos pressupostos teóricos dos campos da Educação, e História Cultural. Trata-se de uma pesquisa do tempo presente, ocorrida entre o período de 2013-2015, do tipo etnográfico com abordagem qualitativa sob a metodologia da História Oral. As práticas educativas encontradas na formação de Dona Dionéia conformam uma educação pautada nos saberes da experiência que perpassam a sua trajetória de vida que a habilitou ao ofício de benzer, curar e educar pessoas, nos permitindo, com isso, pensar a educação em seu sentido alargado, e em uma pedagogia do cotidiano.

Palavras-chave: Educação. Memória. Trajetória de vida.

\section{ABSTRACT}

This article analyzes the formation of Odinéia dos Santos Barbosa, as evangelical healer of the quilombola community of Abacatal - PA. It is based on the theoretical presuppositions of the fields of Education, and Cultural History. This is a present-day research, conducted between the period 2013-2015, of the ethnographic type with a qualitative approach under the Oral History methodology. The educational practices found in the formation of Dona Dionéia conform an education based on the knowledges of experience that permeate her life trajectory that enabled her to bless, heal and educate people, allowing us to think education in its broad sense, and in an everyday pedagogy.

Keywords: Education. Memory. Life trajectory.

\section{RESUMEN}

Este artículo analiza la formacion de Odinéia de los Santos Barbosa, como curadora evangélica de la Comunidad quilombola de Abacatal - PA. Se basa en los presupuestos teóricos de los campos de la Educación, e Historia Cultural. Se trata de una investigación del tiempo presente, ocurrida entre el período de 2013-2015, del tipo etnográfico con abordaje cualitativo bajo la metodología de la Historia Oral. Las prácticas educativas encontradas en la formación de Doña Dionéia conforman una educación pautada en los saberes de la experiencia que atraviesan su trayectoria de vida que la habilitó al oficio de bendecir, curar y educar a las personas, permitiendo, con ello, pensar la educación en su sentido ampliado y en una pedagogía de lo cotidiano.

Palabras clave: Educación. La memoria. Trayectoria de vida.

\footnotetext{
1 Universidade do Estado do Pará - UEP - Pará - Brasil

2 Universidade do Estado do Pará - UEP - Pará - Brasil
} 


\section{INTRODUÇÃO}

Este artigo analisa a formação de Odinéia dos Santos Barbosa - Dona Dionéia, 55 anos, como curadora evangélica, cuja prática se assenta no enfrentamento de doenças físicas e espirituais, no ensino de terapêuticas e também da doutrina evangélica. A Comunidade quilombola de Abacatal, localizada a $08 \mathrm{~km}$ do centro de Ananindeua-PA é o lócus central de sua prática educativa e circulação de saberes. Metodologicamente, este estudo resulta de uma pesquisa realizada no período de 2013 a 2015, caraterizada como do tipo etnográfico, com abordagem qualitativa, sob a metodologia da História Oral e revisão blibliográfica. Teoricamente, situa-se no campo da educação em sua interface com a História Cultural, como uma entre outras possibilidades de análise de sujeitos como Dona Dionéia e sua experiência sociocultural.

Durante a pesquisa exploratória, o nome de Dona Dionéia emergiu entre os moradores da comunidade como benzedeira experiente no enfrentamento de doenças. Este fato nos conduziu à sua residência para uma primeira abordagem, marcando o início da pesquisa de campo e do levantamento de dados. Na trajetória de vida dessa curadora, reconstituída em suas reminiscências e narrativas orais, encontramos os traços de uma pedagogia outra que a formou e a habilitou ao ofício de benzer, curar e educar pessoas em Abacatal.

O caráter etnográfico da pesquisa, ao coadunar-se com a História Oral, objetivou compreender as interações socioculturais tecidas por Dona Dionéia e seus familiares, com os quais aprendeu a curar, e o modo como constituiu a sua cosmologia. Os caminhos percorridos por ela revelam uma experiência intercultural, considerando sua inserção em diversos espaços religiosos: no meio católico, a partir de sua participação no grupo de mulheres, na realização de novenas nos lares de Abacatal e no culto aos santos; na proximidade com entidades do panteão afro-religioso, a exemplo das caboclas Mariana e Jarina, caboclos Rompe-mato e José Tupinambá e outros seres encantados que faziam parte do seu convívio familiar; e na igreja evangélica Assembleia de Deus, onde passou a traduzir e reinventar os saberes herdados de seus antepassados. Na interface do campo da Educação com a História Cultural, vislumbramos a mescla religiosa que the possibilitou criar uma pedagogia do cotidiano, permitindo-nos, assim, apreender a educação em suas múltiplas dimensões.

\section{A EDUCAÇÃO COMO PRÁTICA COTIDIANA}

Na obra "O que é Educação", Carlos Rodrigues Brandão procurou conceituar a educação a partir das dimensões que atravessam o cotidiano da vida dos sujeitos em sociedade mostrando que a arte de educar é milenar e antecipa a sua institucionalização. Mostrou também a ambiguidade da educação, uma vez que ela pode tanto libertar uma sociedade como subjugá-la em benefício do opressor. Para o autor, a educação que possibilita aos homens e mulheres serem efetivamente livres, pode também ensinar "uns a serem senhores e outros, escravos ensinando-os a pensarem, dentro das mesmas ideias e com as mesmas palavras uns como senhores e outros como escravos" (BRANDÃO, 2007 , p. 34). Essa ambiguidade é parte das contradições sociais tecidas pelos homens no espaçotempo. Os processos de produção dos sujeitos e suas pedagogias como inexistentes, à margem de 
uma educação bancária que reproduz desigualdades, por exemplo, conformam uma dialética que se reproduz nos modos como esses sujeitos apreendem a sua realidade subalterna, traduzem-na e reinventam o mundo em que vivem por meio de pedagogias outras, concorrendo, desse modo, com as ideologias e mecanismos sociais hegemônicos.

Segundo Freire (1996), a educação que se revela alienada e alienante, pode ser transformada pelos sujeitos históricos em força de mudança e libertação, ou seja, as tomadas de consciência que as sociedades colonizadas assumem no enfrentamento de formas de dominação partem de um saber que se ancora na experiência, na tradução da sua realidade. Trata-se de um estado de produção de conhecimento que os sujeitos realizam a partir das suas experiências compartilhadas.

Por experiência, compreendemos tudo aquilo que nos toca, que nos é significativo, que provoca mudanças em nossas formas de ser e estar no mundo e de interpretá-lo. Para Bondia (2002), sujeito e ação conformam a experiência. De modo que o sujeito é o protagonista da ação atuando de forma subjetiva, enquanto a ação compreende o relacionamento com a vida de forma reflexiva. A experiência, portanto, é tudo o que acontece ao homem, tudo aquilo que o toca, mas nunca desprovida de sentido. Logo, educar-se com os outros possibilita a construção de um saber da experiência "que se dá na relação entre o conhecimento e a vida humana" (Ibid., 2002, p. 26).

A experiência humana inscrita em Bondia (2002) é também sabedoria popular, educação, porque parte das relações socioculturais dos sujeitos e seus grupos sociais em seus tempos e espaços, seus saberes, suas gramáticas, não desprovidas de intencionalidade. Desse modo, pensamos a educação como cultura, como prática de transformação social em seu sentido amplo, para além dos limites da instituição escolar. Segundo Brandão (2002, p. 139), "toda a teoria da educação é uma dimensão parcelar de alguns sistemas motivados de símbolos e de significados de uma dada cultura ou do lugar social de um entrecruzamento de culturas".

Segundo Martinic (1977), a sabedoria popular cria, a seu modo, movimentos socioculturais ancorados na experiência, na tradução das relações cotidianas, nas educações convergentes ou não ao modelo escolar que fundamenta parâmetros, métodos de interpretação do conhecimento que as sociedades, sobretudo as colonizadas, sombreadas pela ciência moderna, acumularam sobre si. Nesse sentido, "os sujeitos, ao serem considerados sábios, não só participam e reproduzem a visão de mundo da qual participam, e sim que podem ser críticos dela e criadores de sua concepção" (Ibid., 1977, p. 84). Dito de outro modo, os sujeitos criam educações, suas práticas educativas.

Por prática educativa, entendemos "toda relação em que há transmissão de conhecimento de qualquer espécie, seja de caráter moral, religioso, técnico ou até mesmo escolar" (CUNHA; FONSECA, 2007 , p. 2). Conhecimentos que se podem expressar nos Saberes Culturais compreendidos por Albuquerque e Sousa (2016), como uma forma singular de compreensão da realidade que se firma na cultura e também nas conexões estabelecidas pelos sujeitos e seus pares com os quais reinventam criativamente o cotidiano, criando táticas de sobrevivência, tradução e transmissão dos seus saberes, valores e tradições.

Dado o cenário controverso e minado no qual a educação parece assentar-se, cumpre destacar a sua maior riqueza, as gramáticas sociais que se deixam flagrar por meio das relações socioculturais de sujeitos ordinários que, num processo de ação-reflexão-ação, recriam seus modos de aprender e 
apreender a sua realidade, nos possibilitando uma compreensão possível do que é educação em seu sentido amplo, para além dos limites da escolarização.

A educação em sentido amplo é tema presente na agenda de pesquisadores da educação, mas também de historiadores influenciados pela História Cultural que, entre outros temas, se ocupam no exame de práticas educativas em suas múltiplas dimensões e espaços, dos quais a escola é um deles. Para Fonseca (2003, p. 56), "a história cultural apresenta-se como um campo historiográfico, caracterizado por princípios de investigação herdados das propostas dos Annales e dotado de pressupostos teórico-metodológicos que Ihe são próprios". Segundo Hunt (1992), com o advento da chamada Nova História, o trabalho de historiadores preocupados com as limitações impostas pelo modelo positivista de escrever a história, motivou o crescente interesse por temas antes silenciados, passando a explorar a vida social e suas múltiplas dimensões.

Um exemplo disso é a virada cultural ocorrida entre as décadas de 1960 e 1990 do século XX, marcada pelas aproximações entre a História e a Antropologia. Burke (2005) observa que o resultado dessa aproximação influenciou diversas disciplinas, entre elas a História, na qual objetos, temas e métodos de estudo tiveram suas dimensões ampliadas na interpretação das relações socioculturais que passaram a realizar. Para Pesavento (2014), a historiografia produzida pela escola dos Annales trouxe novas perspectivas de pesquisa histórica. Ela culminou no surgimento de novas categorias de estrutura e conjuntura, conceitos identificadores da longa e média duração, além de delinear novos marcos explicativos no tocante à temporalidade presente nos estudos históricos.

Conforme Burke (2005), três gerações de historiadores da Nova História (1929-1989) marcaram profundamente o fazer historiográfico do século XX. Na vanguarda da produção de pesquisas envolvendo novos objetos, percebe-se o surgimento de uma dimensão epistemológica do fazer historiográfico, marcada pelas contribuições de diferentes campos do conhecimento, a Nova História Cultural.

A Nova História Cultural buscou também "trazer à tona o individuo, como sujeito da História, recompondo histórias de vida, particularmente daqueles egressos das camadas populares" (PESAVENTO, 2014, p. 118). Trata-se, portanto, de um campo multidisciplinar que atua sobre diversos temas e objetos de estudos, entre os quais podemos inserir as práticas educativas cotidianas, saberes culturais, outras pedagogias, como é o caso da formação de Dona Dionéia.

Formas alternativas de educar e que se processam no cotidiano, como as de Dona Dionéia, denunciam o lugar de invisibilidade que esses saberes ainda ocupam perante o saber institucionalizado, forjado pela modernidade. O silenciamento dessa experiência é também seu maior desperdício, pois o saber que é mediado e posto em circulação por Dona Dionéia é pautado na cultura, possui materialidade, mistura de religiosidade e religião e é transmitido por meio de práticas educativas, posto que reflete um modo de curar e educar no cotidiano. Nesse sentido, a Histórica Cultural como campo teórico privilegiado nesse trabalho, problematiza o modo canônico de uma histórica episódica, factual, trazendo à tona sujeitos e processos educativos singulares como o objeto do presente estudo. 


\section{SABERES NA TRAJETÓRIA DE VIDA DE UMA EDUCADORA AMAZÔNIDA}

As entrevistas com Dona Dionéia foram realizadas à sombra de uma mangueira ou no interior da igreja Assembleia de Deus, em Abacatal, buscando-se, conforme nos inspirou Thompson (1992), um local em que a narradora se sentisse à vontade.

Ao falar sobre a sua passagem pela instituição escolar, Dona Dionéia afirma que havia estudado só até o terceiro ano do ensino fundamental em Belém, onde passou apenas três anos. Em suas palavras, "Eu fui pra casa da minha tia, lá eu passei três anos [...] aí, ele [seu pai] mandou meu irmão me buscar porque ele tinha levado uma mordida de cobra. Eu vim embora, aí ele não deixou mais eu estudar" (Entrevista, 5 abr. 2013).

A narrativa de Dona Dionéia sobre o seu envolvimento com o universo escolar permite inferir que ela foi educada pelo próprio núcleo familiar a exemplo de muitas outras pessoas de seu tempo em Abacatal. $O$ que certamente não imaginava é que a educação que receberia a levaria ao posto de curadora de enfermidades físicas e espirituais, entre elas a benzedura. Em suas palavras,

\footnotetext{
Eu era novinha, é, acho que eu tinha uns 14 anos... Faz muito tempo... Foi minha madrinha que me ensinou a benzer, também porque o meu irmão tava ruim, e ele tava doente e não podia sair de casa. Eu foi lá chamar ela, pra ela orar por ele que tava com muita febre, Aí ela disse: Eu também tô com febre, minha filha, eu não posso, mas eu vou te ensinar. Tu sabe o 'crendeuspai', o Pai Nosso? Eu disse: sei. Pois então, eu vou te ensinar só como cortar as rosas e aí tu faz, aí tu corta e depois tu faz a oração, ora em cima que ai ele vai ficar bom. Ela mandou eu escrever, eu escrevi, aí eu decorei de cabeça. Aí eu já sabia o pai nosso e o 'crendeuspai' (Entrevista, 21 dez, 2013).
}

Nessa narrativa percebemos um processo educativo cotidiano envolvendo sua madrinha, Dona Minervina, como educadora e Dona Dionéia como aprendiz da técnica da benzedura. Essa técnica mobilizou o saber mágico-religioso expresso por meio das orações cristãs católicas ( Pai Nosso e Creio em Deus Pal); o uso da jaculatória (a reza específica para afastar a doença na benzeção, implícita nessa narrativa); a alfabetização (saber ler e escrever); a memorização (decorar de cabeça todas as etapas da benzedura); a observação (seguir passo a passo as etapas do processo de intercessão em prol da cura do enfermo); e a fé, como expressão cosmológica que envolve todo o processo de enfrentamento da doença, sendo esta última uma irrupção do cotidiano por se tratar de algo não esperado pelos indivíduos (QUINTANA, 1999).

Conforme Bosi (2003), a memória é guardiã das experiências vividas e por isso possibilita a manutenção dos códigos culturais dos sujeitos em tempos e espaços outros. Tal compreensão permite afirmar que os saberes cotidianos com os quais Dona Dionéia passou a lidar, a partir de seus 14 anos, estão inscritos em sua memória individual e pertencem à cultura do seu grupo familiar. Logo, a memória individual de Dona Dionéia está ligada à memória do núcleo familiar ao qual pertence.

A memória individual depende da memória coletiva e com ela deve estabelecer íntima dependência, ou seja, é preciso que ela "não tenha deixado de concordar com as memórias deles [do grupo] e que existam muitos pontos de contato entre uma e outras para que a lembrança que nos 
fazem recordar venha a ser reconstruída sobre uma base comum" (HALBWACHS, 2003, p. 39). O caráter coletivo que essa memória assume, neste caso, refere-se aos saberes e práticas curativas desenvolvidas pelos membros da família de Dona Dionéia, presentes em suas memórias e transmitidos a ela no cotidiano de suas experiências. Em suas palavras,

Minha mãe, ela era formada! Uma vez uma menina tava com uma criança em pé dentro da barriga, aí ela mandou que levantasse ela e aí seguraram e ela orou na barriga dela. Aquela criança nasceu direitinho. Minha mãe sabia orar. Minha mãe era benzedeira, parteira, ela sabia muita coisa, ela era médium. Ela trabalhava com guia, mas eu não lembro direito porque eu era criança (Entrevista, 5 abr, 2014).

Na expressão "minha mãe era formada", verifica-se a importância de determinada formação para o enfrentamento de doenças e outros males espirituais. Essa formação se dá na experiência pedagógica presente nas relações socioculturais, tecidas entre os sujeitos e os seres espirituais revelando o cotidiano como peça chave nesse processo educativo. Longe de ser uma repetição diária, o cotidiano, segundo Certeau (2009) é constituído de uma dimensão social que abriga as muitas formas da vida em sociedade e sua singularidade se deixa flagrar nas formas inventivas com que os sujeitos se relacionam e criam suas táticas de sobrevivência, como se vê na relação de Dona Dionéia e seus familiares na tradução da doença e dos meios para enfrentá-la.

Entre os membros da família de Dona Dionéia, com quem diz ter aprendido sobre as doenças e o conhecimento sobre as terapêuticas estão: Dona Suzana, parteira, benzedeira, tia do senhor Manoel, esposo de Dona Dionéia; Carlos Alberto, cunhado de Dona Dionéia, pajé que trabalhou durante algum tempo com entidades como a cabocla Mariana, a cabocla Jarina e Rompe-mato; Manoel dos Santos Barbosa, benzedor; e, finalmente, Dona Minervina, com quem Dona Dionéia aprendeu a benzer enquanto pertencia a comunidade católica do Sagrado Coração de Jesus, em Abacatal.

O exercício de curar estava disseminado entre os familiares de Dona Dionéia e foi com eles que ela diz ter aprendido a conhecer as malinesas das doenças físicas e espirituais, bem como tratálas, a exemplo dos chás e banhos espirituais feitos com plantas medicinais e óleo consagrado, garrafadas e xaropes, muitas vezes mesclados com algum medicamento alopático que aprendeu durante uma consulta ambulatorial. Ao falar sobre os medicamentos aprendidos com o serviço médico, assim narrou: "às vezes a gente vai no médico, aí eles passam a receita, aí aquele remédio foi bom pras crianças, vamos dizer assim, o Infectrin foi bom, aí eu guardo aquela receita" (Entrevista, 5 abr. 2014).

A prática de Dona Dionéia como benzedeira se manteve durante toda a sua permanência na Igreja Católica. Orações como "Pai Nosso", "Ave Maria", "Creio em Deus Pai" e "Salve Rainha" estavam presentes nos atendimentos que ela realizava para afastar a "batida de bicho" - doença espiritual causada por seres encantados nas matas - ou para cortar a erisipela, mas também orientavam as muitas novenas que realizava no seio de sua parentela. Conforme ela conta: 
Eu sempre participei de comunidade. Eu era da frente, louvava junto com as mulheres, aí do Sagrado Coração de Jesus. Aí, a gente fazia novena de noite, dia do círio, negócio de natal, tudo do círio daqui, do Sagrado Coração de Jesus. Cada noite era numa casa, cada casa tinha que fazer o seu, sua novena. Aí, eu já fazia com a minha filha e vinha um bocado [de gente] traziam a santa (Entrevista, $21 \mathrm{dez}, 2013)$.

Durante as programações festivas do Círio da comunidade, no mês de junho, bem como as festividades do Círio de Nossa Senhora de Nazaré, no mês de outubro, são realizadas novenas nos lares católicos de Abacatal com a participação do grupo de mulheres que Dona Dionéia fez parte. Nessas novenas estão presentes as orações, como "Ave Maria", "Pai Nosso", "Creio em Deus Pai", "Salve Rainha", leituras do Evangelho e pedidos de intercessões dirigidos aos santos. Estes elementos compõem os saberes compartilhados naqueles momentos entre Dona Dionéia e seus pares, mediados pela cultura material como o terço ou rosário, a bíblia, hinários ou livro de cânticos, imagens dos santos, velas, entre outros elementos ali presentes.

Dona Dionéia esteva, por muitos anos, engajada nas atividades religiosas do meio católico de Abacatal. Sua relação com os demais fiéis sugere que ela era uma figura popular entre os membros da igreja. No fragmento de sua narrativa, abaixo, observa-se que certo número de pessoas visitava sua residência por ocasião da novena, fato que a colocava numa relação de alteridade perante seus parentes e amigos: "cada noite era numa casa, cada casa tinha que fazer o seu, sua novena. Aí, eu já fazia com a minha filha e vinha um bocado [de gente] e traziam a santa" (Entrevista, $21 \mathrm{dez}, 2013$ ).

A reunião de devotos mediada pela fé nos santos, o uso de objetos sagrados, as rezas e os pedidos de intercessões revelaram não apenas o caráter religioso e educativo da novena, mas também a sua influência sobre a formação católica de Dona Dionéia. Até certo momento de sua vida ela pertenceu ao rol de devotos do Sagrado Coração de Jesus em Abacatal. Foi membro do grupo de mulheres que louvava nas programações da igreja; participou ativamente das peregrinações dos santos; atuou na realização de novenas e ainda permaneceu benzendo, unindo os saberes católicos à arte de curar. Todavia, uma série de acontecimentos envolvendo sonhos, premonições e problemas de saúde mudaram profundamente a sua vida e a maneira como passou a se relacionar com a Igreja Católica, sua família e com as práticas religiosas que antes se identificava. Dona Dionéia tornou-se evangélica.

O ano demarcado por Dona Dionéia em suas reminiscências para registrar sua inserção na seara evangélica e a introdução do ministério denominado Igreja Pentecostal Assembleia de Deus, na Comunidade de Abacatal, foi 2007. Seu encontro com a nova fé teve início após uma sequência de episódios, entre os quais destacou dois sonhos com sua falecida mãe, sua internação no hospital para a realização de uma intervenção cirúrgica e a perda prematura de um filho/neto ocorrida no hospital municipal de Curuçá-PA. Ao descrever os sonhos que teve com sua falecida mãe, Dona Dionéia, assim narrou: 
Eu sonhei com a mamãe duas vezes. Eu teve esses sonhos antes de eu aceitar a Jesus. Eu sonho com a mamãe que ela não tá bem. Eu sonhei a primeira vez com a mamãe que ela tava costurando numa porta, sentada na porta, costurando. Aí, eu olhei pra dentro, tava muito escuro. Eu disse assim, mamãe o que a senhora tá fazendo no escuro? Aí, ela dizia assim pra mim, não vem pra cá, vai-te embora pra casa do teu pai... não vem pra cá. Aí, eu não entrava porque ela não deixava. Era uma casa simples, comprida... Passou muito tempo, eu sonhei que ela tava assim, num roçado, ela tava apagando fogo, tinha muita fumaça, muito fogo. Aí, disque eu dizia assim, mãe, o que a senhora tá fazendo aí no fogo? Ela dizia, minha missão! Eu dizia, o que a senhora tá fazendo nesse fogo? Tem muita fumaça! Ela dizia, não vem pra cá! Aí eu dizia então eu vou embora. Aí, eu ficava triste e aí eu ia entrando num caminho limpo, eu ia numa estrada limpa. Aí ela dizia pra mim, não vai por aí! Por aí tem abismo! Eu dizia, como assim? Ela dizia, é, tem abismo. Eu obedecia. Ela disse vai por aí nesse caminho. Caminho cerrado, cerrado, todo molhado, [eu dizia] mas esse caminho tá muito molhado, só juquiri! Mas ela disse, vai por ele, tu tem que andar nele. Aí, eu entrava nele. Quando eu entrava vinha uma força assim, tipo um vento, e me tirava, assim... Aquilo me levava assim, eu ia subindo, né, eu ia por cima do mato, parece assim que eu ia pisando numa coisa, mas não tinha nada. Eu era levada pelo vento. Aí, eu olhava pra estrada que [antes] eu ia seguir, era um tormento, um abismo muito grande. Eu via muita gente gritando e chorando e gemendo e aquela gente caindo, gente morta, tinha assim uma coisa ruim, sabe... aí eu passava e ia embora. Eu ficava com pena daquelas pessoas, eles sofriam (Entrevista, 5 abr, 2014).

Dona Dionéia recria em seus sonhos traços do cristianismo católico e evangélico. Os lugares descritos em sua narrativa sugerem o purgatório católico cristão, um entre-lugares onde as almas esperam o juízo de Deus. Os espaços descritos por Dona Dionéia, onde sua falecida mãe aparece uma casa escura, em meio ao fogo - são sugestivos a um ambiente de solidão e sofrimento, característicos do purgatório. Com o semblante sério, olhar distante e voz firme, Dona Dionéia deu a sua interpretação dos sonhos que teve com a sua mãe: "No meu sentimento foi o que veio, ela quer que eu sirva a Jesus. Porque está na Bíblia, Jesus é o caminho, a verdade e a vida, ninguém vai ao pai se não for por ele (João 14.6). Eu fico pensando assim, que era isso que ela queria" (Entrevista, 5 abr., 2014).

Dona Dionéia teceu a sua análise sobre a condição póstuma de sua mãe sob as lentes do pentecostalismo evangélico, embora encontremos em sua narrativa traços da tradição católica, como o purgatório, mescladas a um saber divinatório ligado às mensagens trazidas nesses sonhos. Mesmo de um lugar de sofrimento, solidão e tristeza sua mãe está realizando sua missão, qual seja, orientá-la quanto à escolha do caminho da salvação, representado pelo caminho cerrado, molhado, "só juquiril", que a levaria de volta à casa do seu pai, representação da igreja. Essa narrativa ratifica a força com que a doutrina evangélica influencia os modos de ser e estar dos sujeitos no mundo. Embora os sonhos de Dona Dionéia prenunciassem sua mudança religiosa, ela não sabia o que o futuro the reservava. Acometida por uma infecção após ser submetida a uma cirurgia, sem perspectiva de alta, Dona Dionéia encontrou nas orações de um grupo evangélico, que visitava o hospital naquele momento, a cura para a sua enfermidade. Segundo ela: 
Olhe, eu aceitei Jesus, porque eu teve que aceitar. Olhe... Eu me operei pra não ter mais filho. Me operei lá em São Brás, numa clínica, a Santa Bárbara. Teve nove dias que não podia urinar. Quando eles tiravam a sonda de mim eu não aguentava de dor, ai eu caia.... Então ela [a enfermeira] disse que enquanto eu não ficasse boa não poderia sair. [...] Quando foi um dia, os crentes estavam orando, cantando lá perto [da enfermaria], eu tava lá em cima com umas meninas. Ai eu começava a me tremer... Ai, eu [pensei] quer saber de uma coisa, eu vou é orar com esses crentes, que eu vou ficar boa. Aí eu me ajoelhei lá né, no pé da cama. Eu não sabia orar que nem eles, né. Eu repetia o que eles tavam falando... Quando eu terminei de orar, eu pedi pra Jesus. Que Jesus me curasse. que eu saísse e viesse embora pra casa. Quando foi de manhã, eu me esqueci... Quando foi tomar banho, ai eu abri o chuveiro lá eu urinei... Olha, sem mentira nenhuma, eu vim embora pra casa... (Entrevista, 28 set, 2013).

O contato inicial com a fé evangélica se deu, portanto, em seu leito no hospital. Entretanto, sua entrada efetiva na igreja, ou seja, sua "conversão" aconteceu tempos depois, após procurar por uma igreja com a qual pudesse se identificar. Ao receber um convite de um pastor da igreja Assembleia de Deus, amigo de seus familiares, sua decisão se concretizou. Em suas palavras: "Aí eu foi. Aí eu achei bonito, sabe. Quando teve um culto de novo eu foi. Eu chorei. Eu me senti assim diferente, né, porque o Espírito Santo, quando ele entra na gente é uma coisa diferente que a gente sente" (Entrevista, 28 set. 2013).

Observa-se em sua narrativa que seu encontro com o sagrado na Igreja Evangélica foi marcado por muita comoção. Ela foi tocada pelo Espírito Santo a ponto de afirmar que em seu corpo sentiu algo diferente. Dias depois dessa experiência espiritual, tomou a decisão de aceitar a Jesus. Em suas palavras: "Quando foi na outra semana, o culto lá era na quarta-feira, ai, esse pastor que a gente conheceu, sabe, disse pra mim assim: A senhora não quer aceitar a Jesus? Aí eu disse: eu quero. Eu aceitei Jesus pelo amor" (Entrevista, 28 set. 2013).

Nos primeiros tempos de nova fé, Dona Dionéia conta que precisou enfrentar uma grande dor, a perda prematura do seu filho/neto. Esse episódio foi, em grande medida, responsável pelo seu retorno a Abacatal e pelo início de um trabalho missionário de evangelização em prol da conversão da comunidade, através da igreja Assembleia de Deus. Ao falar sobre essa experiência, ela comenta:

[Eu] Tinha um filho, João Carlos, que não era meu, era da Cacilda, ela me deu. Ela me disse, mãe, fique com esse menino pra senhora. Eu já estava cuidando dele. Meu marido mandou registrar. Pra mim, foi os médicos que mataram ele pra lá [no hospital]. Só aplicaram uma injeção nele. Ele chegou lá andando, gordo. Ele era bonito, o meu filho... Foi só ele chegar lá, aplicaram uma Dipirona nele com Plasil, pra vômito. Ele tava com vômito. Eu não morava aqui [Abacatal] lá onde eu morava não tinha como eu fazer um remédio pra ele, sabe como é? (Entrevista, 14 mar. 2015).

Segundo Dona Dionéia, a perda de seu filho abalou muito sua família. Distante de sua farmacopeia natural, ela se queixa de não ter tido a oportunidade de cuidar da saúde dele, por estar distante de Abacatal. Após o falecimento de seu neto, o regresso à comunidade foi inevitável. Tendo a chance de trilhar um novo caminho espiritual para si e para os seus pares, Dona Dionéia retornou à Abacatal e passou a reconstruir sua prática de cura e identidade religiosa de um modo muito peculiar. 
A partir de então, sob as lentes evangélicas, começou a interpretar a realidade a sua volta exorcizando sua prática religiosa anterior, como se pode verificar na narrativa a seguir:

Eu andava aí, estava aí eu andava na missa, ia pros cultos, ia pro Círio do Sagrado Coração de Jesus. Eu ia. Então, nós adorava aquela imagem e você sabe, não pode adorar imagem. Porque não dá pra adorar imagens de esculturas. Devemos amar primeiramente a Ele e amar o nosso próximo como a nós mesmos (Entrevista, 14 mar. 2015).

Esse passado religioso que Dona Dionéia tenta silenciar também se projeta sobre a sua atuação como uma agente da cura na comunidade. Ao ser indagada sobre a sua missão, ela explica que apesar de ser ensinada na igreja evangélica a não prosseguir com a benzeção, por exemplo, ela permanece utilizando a educação que recebeu durante a sua passagem pela igreja católica, e as experiências com seus familiares em prol da cura dos necessitados. Em suas palavras: "Eu interpreto uma coisa [...] que a pessoa está precisando ser curada. Eu estou fazendo uma missão que Deus deixou" (Entrevista, 14 mar. 2015).

Nas reuniões de oração, no estudo dos evangelhos, e ainda nas mediações feitas pelo pastor da igreja Assembleia de Deus em Abacatal, Dona Dionéia reinventa sua cosmogonia e também os saberes que apreendeu durante a sua passagem pelo catolicismo e em seu núcleo familiar. Elementos como a mídia televisiva emergiram em sua narrativa como parte do processo de sua formação como curadora. Por meio da televisão, Dona Dionéia entrou em contato com programas evangélicos, como $o$ show da fé, dirigido pelo pastor presidente da Igreja Neopentecostal Internacional da Graça, com quem disse aprender várias lições. Sobre essa experiência, assim relata: "[...] ele ora, ele apresenta a todos e pede a saúde pra todos. Ele ensina que a gente tem que amar o nosso próximo. Amar primeiro a Deus, [...] e levar a mensagem de Cristo, o evangelho a toda a criatura" (Entrevista, 14 mar, 2015).

O conteúdo apreendido por Dona Dionéia ao assistir o programa evangélico confunde-se com aquele que ela recebeu na Igreja Assembleia de Deus, por meio das orientações do pastor e pela leitura da bíblia. Esses aspectos nos reportaram às conjecturas de Chartier (1991) acerca dos modos diferenciados como os indivíduos realizam suas leituras de textos, eruditos ou não, e os interpretam, criando sentidos para si e partilhando com os outros segundo sua cultura, tempo e espaço. Para Chartier (1991, p. 178), "a leitura não é somente uma operação abstrata de intelecção: é por em jogo o corpo, é inscrição num espaço, relação consigo e com o outro". A leitura, portanto, independe do grau de intelectualidade para existir e sua multiplicidade de formas e possibilidades de interpretação de um mesmo texto pode, em certa medida, revelar as práticas culturais dos sujeitos históricos.

A narrativa de Dona Dionéia é perpassada por temas e mensagens bíblicas de cunho apocalíptico, bem como por passagens que denotam arrependimento e amor ao próximo. A partir da leitura particular da bíblia, da interpretação dos ensinamentos católicos e evangélicos, construiu a sua cosmogonia.

Ao destacar-se entre os membros da igreja evangélica, Dona Dionéia conta que foi consagrada pelo pastor para o trabalho de evangelização. Para tanto, teve suas mãos lavadas com óleo ungido, 
como ato simbólico de autoridade, para poder impor suas mãos sobre aquelas pessoas das quais fosse expulsar o mal. Segundo ela, "ele orou em mim [...] Me ungiu com óleo. Então, ele ungiu minha mão. Aí ele disse que eu tava preparada pra orar nas pessoas com o óleo" (Entrevista, 14 mar. 2015).

Dona Dionéia contou que para lidar com as limitações que a sua nova identidade religiosa lhe impôs, sobretudo em relação às práticas de cura que herdou dos seus antepassados, precisou assumir-se oradora e não mais benzedeira perante a comunidade de Abacatal. Em suas palavras, "eu me considerava [benzedeira] e hoje eu me considero uma oradora. Eu tô orando nas pessoas que precisam de oração" (Entrevista, 14 mar. 2015).

Pode-se dizer, então, que a reinvenção feita por Dona Dionéia se revela como um evento substancial de tomada de consciência, que se fez sentir na seleção dos saberes que permaneceriam fazendo parte de seu trabalho de cura, na forma como passou a se autodenominar "oradora", e no modo como passou a influenciar religiosamente as pessoas que atende.

Embora o poder social e normativo da igreja evangélica a tenha influenciado, é possível perceber que as identidades de Dona Dionéia coexistem e se reinventam no espaço da cura nos aproximando da ideia de identificação proposta por Hall (2014) ao sugerir que não se pode pensar a identidade como algo acabado, mas como um processo em andamento.

Dado o caráter ambíguo da identidade religiosa de Dona Dionéia, a sua formação como curadora the possibilitou reinventar o espaço da cura em Abacatal. Entre benzeduras, novenas e trânsitos religiosos, Dona Dionéia é formada em uma pedagogia viva e singular que nasce do encontro entre religião e educação ancoradas no saber da experiência dos mestres e tradutores do mundo físico e espiritual, a saber, seus familiares e posteriormente, seu pastor que the iniciou na doutrina evangélica.

Dona Dionéia é, portanto, um sujeito histórico que transita entre universos religiosos, e conhecimentos historicamente constituídos por seus antecessores. Tais elementos a possibilitaram extrair dessas culturas conhecimentos e habilidades identificados como saberes ambientais, utilizados na coleta de matérias-primas, na mata, necessárias à fabricação de terapêuticas; saberes religiosos, referentes à sua cosmogonia forjada na relação entre o catolicismo, seres encantados, pentecostalismo evangélico e o espaço da cura em Abacatal; saberes medicinais, conjunto de habilidades que the permite ler os sintomas e identificar as doenças e explicar a suas causas que pode ser física e/ou espiritual; saberes corporais, conjunto de técnicas apreendidas nos atos ritualísticos dentro e fora do espaço religioso, mas também na produção de banhos, chás, entre outras terapêuticas.

\section{CONSIDERAÇÕES FINAIS}

Este artigo analisou o processo pedagógico de formação de Odinéia dos Santos Barbosa, conhecida como Dona Dionéia, curadora evangélica cuja prática se assenta no enfrentamento de doenças físicas e espirituais, no ensino de terapêuticas e também da doutrina evangélica. Verificou-se que os saberes presentes em sua prática educativa foram constituídos durante sua trajetória de vida. 
O trabalho evangelístico realizado por Dona Dionéia representa, portanto, a reafirmação de sua identidade perante a comunidade de Abacatal. Fosse evangelizando ou impondo as mãos sobre os enfermos, ela mostra o lugar de onde passou a interpretar a vida, o que implicou no seu afastamento das antigas práticas de benzedura.

Ao longo de sua mocidade, Dona Dionéia mobilizou conhecimentos herdados de seus familiares sobre o enfrentamento de doenças físicas e espirituais e os mesclou, anos mais tarde, aos saberes apreendidos na igreja evangélica. O conjunto de saberes - ambientais, religiosos, medicinais e corporais - forjados ao longo de sua trajetória conforma uma relação eminentemente pedagógica cuja lógica se assenta na oralidade com que aprendeu a conhecer e enfrentar as doenças; na memória individual e coletiva, onde a transmissão de seus códigos culturais, cosmogonias e experiências de vida estão ancorados e, assim, reinventados no tempo presente; no cotidiano, palco de sua experiência sociocultural; na religiosidade, forjada no trânsito religioso entre o catolicismo e o pentecostalismo evangélico e, por fim, na corporeidade que se expressa em todo o processo mágico-religioso que permeou sua formação.

Como subversão às imposições ditadas pelo modelo hegemônico de produção do conhecimento, sujeitos como Dona Dionéia emergem das sombras trazendo consigo o legado de seus mestres, práticas de cura, modos de educar que lhes são particulares, mas que operam em conexão aos demais conhecimentos, como as mesclas entre fármacos alopáticos e tradicionais presentes em sua farmacopeia.

Produzidas como subalternas e inexistentes, as formas de educação que se ancoram em critérios de inteligibilidade distintos dos modelos estabelecidos pela racionalidade moderna concorrem em seu turno em busca de espaços que promovam a projeção da voz do outro, do subalterno, de suas experiências socioculturais, suas pedagogias. Na perspectiva microscópica deste estudo sobre a trajetória de vida de Dona Dionéia e a sua formação como curadora, repousa a intenção de contribuir com a escrita de uma história cultural da educação na Amazônia, sobretudo, no enlace entre os saberes que curam e educam, mobilizando, para tanto, um conceito amplo de educação, vista como cultura.

$\mathrm{Na}$ trajetória de Dona Dionéia encontramos os traços significativos de uma pedagogia outra, cuja prática enseja o redimensionamento do conceito de educação, para além do reduto escolar. Cabe ainda indagar como Dona Dionéia passou a ensinar o que aprendeu em sua formação, mas este é um assunto para outras reflexões.

\section{REFERÊNCIAS}

1. ALBUQUERQUE, Maria Betânia Barbosa; SOUSA, Marcio Barradas Sousa. Saberes Culturais. In: Uwakürü: dicionário analítico. ALBUQUERQUE, Gerson Rodrigues de. PACHECO, Agenor Sarraf . (Orgs.), Rio Branco: Nepan Editora, 2016, p. 230-250. Disponível em: 
$<$ http://www.mel.unir.br/uploads/56565656/arquivos/Uwa_k_r_Dicion_rio_Anal_tico_1877679675.p df>. Acesso em 01 de jun. de 2019.

2. BARBOSA, Odinéia dos Santos. Dona Dionéia: depoimentos. Entrevistador: Marcio Barradas de Sousa. Abacatal, Ananindeua-PA, set. 2013a. 1 arquivo de áudio. (Entrevista para composição de dados da Dissertação).

3.

Dona Dionéia: depoimentos. Entrevistador: SOUZA, Marcio Barradas de Sousa. Abacatal, Ananindeua-PA, dez. 2013b. 1 arquivo de áudio. (Entrevista para composição de dados da Dissertação).

Dona Dionéia: depoimentos. Entrevistador: SOUZA, Marcio Barradas de Sousa. Abacatal, Ananindeua-PA, abr. 2014. 1 arquivo de áudio. (Entrevista para composição de dados da Dissertação). . Odinéia dos Santos. Dona Dionéia: depoimentos. Entrevistador Marcio Barradas de Sousa. Abacatal, Ananindeua-PA, mar. 2015. 1 arquivo de áudio. (Entrevista para composição de dados da Dissertação).

6. BONDÍA, Jorge Larrosa. Notas sobre a experiência e o saber de experiência. Revista Brasileira de Educação, Rio de Janeiro, v. 1, n. 19, p. 20-28, abr. 2002.

7. BOSI, Ecléa. O tempo vivo da memória: ensaios de psicologia social. São Paulo: Ateliê Editorial, 2003. A Educação Como Cultura. São Paulo: Brasiliense, 2002.

9. O que é Educação. São Paulo: Brasiliense, 2007. BURKE, Peter. O que é História cultural? Rio de Janeiro: Jorge Zahar Editor, 2005. CERTEAU, Michel de. A invenção do cotidiano: 1. Artes de fazer. 16. ed. Tradução de Ephraim Ferreira Alves. Petrópolis: Vozes, 2009.

CUNHA, Paola Andrezza Bessa; FONSECA, Thais Nívia de Lima e. Educação e religiosidade: as práticas educativas nas irmandades leigas mineiras do século XVIII nos olhares de Debret e Rugendas. In: SIMPÓSIO NACIONAL DE HISTÓRIA, 23., 2005, Londrina. Anais... Londrina: ANPUH, 2005. CD-ROM. 
13. FONSECA, Thaís Nívea de Lima e. História da Educação e História Cultural. In: FONSECA, Thaís Nívea de Lima; VEIGA, Cynthia Greive (Orgs.). História e Historiografia da educação no Brasil. Belo Horizonte: Autêntica, 2003. pp. 49-75.

14. FREIRE, Paulo. Pedagogia da autonomia: Saberes necessários à prática educativa. São Paulo: Paz e Terra, 1996 - Coleção leitura).

15. HALBWACHS, Maurice. Memória individual e coletiva. In: A memória Coletiva. Tradução de Beatriz Sidou. São Paulo: Centauro, 2003. pp. 29-70.

16. HALL, Stuart. A identidade cultural na Pós-Modernidade. Tradução de Tadeu da Silva \& Guacira Lopes Louro. Rio de Janeiro: Lamparina, 2014.

17. HUNT, Lynn. A nova história cultural. Tradução de Jefferson Luiz Camargo. São Paulo: Martins Fontes, 1992.

18. MARTINIC, Sergio. Saber popular e identidade. In: GADOTTI, Moacyr; TORRES, Carlos Alberto (Orgs.). Educação popular: utopia latino-americana. São Paulo: Cortez, 1994. pp. 69-88.

19. PESAVENTO, Sandra Jatahy. História \& História Cultural. 3. ed. $1^{\text {a }}$ reimp. Belo Horizonte: Autêntica Editora, 2014.

20. QUINTANA, Alberto Manuel. A ciência da benzedura: mau-olhado, simpatias e uma pitada de psicanálise. São Paulo: EDUSC, 1999.

21. THOMPSON, Paul. A voz do passado: história Oral. Tradução de Lólio Lourenço de Oliveira. Rio de Janeiro: Paz e Terra, 1992.

\section{Marcio Barradas Sousa}

Mestre em Educação pela Universidade do Estado do Pará na linha de pesquisa Saberes Culturais e Educação na Amazônia. Possui Licenciatura em História com Especialização em Ensino de História do Brasil. É, também, especialista em Educação em Saúde. Membro do Grupo de Pesquisa História da Educação na Amazônia (GHEDA), vinculado ao Programa de Pós-Graduação em Educação da Universidade do Estado do Pará. Tem experiência profissional na área da Educação e da Saúde.

\section{Jane Elisa Otomar Buecke}

Mestre em Educação pelo no Programa de Pós-graduação da Universidade do Estado do Pará (PPGED - UEPA). Especialista em Gestão Escolar pela Universidade do Estado do Pará (2003) e Licenciada em Pedagogia pela Universidade Federal de Viçosa (1996). Tem experiência na área de 
gestão escolar e docência no ensino fundamental e no magistério das matérias pedagógicas. Pesquisadora vinculada à Associação Nacional de Pesquisa e Pós-Graduação em Educação (ANPEd). Interessa-se pela pesquisa em História da Educação na Amazônia com ênfase nas práticas educativas não escolares e história da infância no período colonial, assentada no campo da História Cultural.

\section{Como citar este documento:}

SOUSA, Marcio Barradas; BUECKE, Jane Elisa Otomar. Pedagogia da cura: formação e práticas cotidianas de Dona Dionéia. Reflexão e Ação, Santa Cruz do Sul, v. 27, n. 3, p. 128-142, out. 2019. ISSN 1982-9949. Disponível em: <https://online.unisc.br/seer/index.php/reflex/article/view/13637>. Acesso em: . doi:https://doi.org/10.17058/rea.v27i3.13637. 